\title{
Bacterial Consumption of T4 Phages
}

\author{
Jean-Jacques Godon ${ }^{1, *}$, Ariane Bize ${ }^{2} \mathbb{D}$, Hoang Ngo $^{2}$, Laurent Cauquil ${ }^{3}\left(\mathbb{D}\right.$, Mathieu Almeida ${ }^{4}$ (D), \\ Marie-Agnès Petit ${ }^{5}$ and Olivier Zemb ${ }^{3, *}$ (D)
}

1 INRAE, Univ Montpellier, LBE, 11100 Narbonne, France

2 PRocédés biOtechnologiques au Service de l'Environnement, INRAE, Université Paris-Saclay, 92761 Antony, France; ariane.bize@inrae.fr (A.B.); hoang.ngo@inrae.fr (H.N.)

3 GenPhySE, INRAE, Université de Toulouse, 31320 Castanet-Tolosan, France; laurent.cauquil@inrae.fr

4 MGP, INRAE, Université Paris-Saclay, 78350 Jouy-en-Josas, France; Mathieu.Almeida@inrae.fr

5 AgroParisTech, Micalis Institute, INRAE, Université Paris-Saclay, 78350 Jouy-en-Josas, France

* Correspondence: jean-jacques.godon@inrae.fr (J.-J.G.); Olivier.zemb@inrae.fr (O.Z.); Tel.: +33-4-68-42-51-54 (J.-J.G.); +33-5-61-28-50-99 (O.Z.)

check for updates

Citation: Godon, J.-J.; Bize, A.; Ngo, H.; Cauquil, L.; Almeida, M.; Petit, M.-A.; Zemb, O. Bacterial Consumption of T4 Phages. Microorganisms 2021, 9, 1852. https://doi.org/10.3390/ microorganisms 9091852

Academic Editor: Michael F. Hynes

Received: 28 June 2021

Accepted: 24 August 2021

Published: 31 August 2021

Publisher's Note: MDPI stays neutral with regard to jurisdictional claims in published maps and institutional affiliations.

\section{Copyright: (c) 2021 by the authors.} Licensee MDPI, Basel, Switzerland. This article is an open access article distributed under the terms and conditions of the Creative Commons Attribution (CC BY) license (https:/ / creativecommons.org/licenses/by/ $4.0 /)$.

\begin{abstract}
The bacterial consumption of viruses not been reported on as of yet even though bacteria feed on almost anything. Viruses are widely distributed but have no acknowledged active biocontrol. Viral biomass undoubtedly reintegrates trophic cycles; however, the mechanisms of this phase still remain unknown. ${ }^{13} \mathrm{C}$-labelled T4 phages monitor the increase of the density of the bacterial DNA concomitant with the decrease of plaque forming units. We used ${ }^{12} \mathrm{C}$ T4 phages as a control. T4 phage disappearance in wastewater sludge was found to occur mainly through predation by Aeromonadacea. Phage consumption also favours significant in situ bacterial growth. Furthermore, an isolated strain of Aeromonas was observed to grow on T4 phages as sole the source of carbon, nitrogen, and phosphorus. Bacterial species are capable of consuming bacteriophages in situ, which is likely a widespread and underestimated type of biocontrol. This assay is anticipated as a starting point for harnessing the bacterial potential in limiting the diffusion of harmful viruses within environments such as in the gut or in water.
\end{abstract}

Keywords: bacteriophage; Aeromonas; stable isotope probing

\section{Introduction}

For any type of bacteria, the presence of viruses may present a significant opportunity for feeding. Indeed, viruses represent 0.2 gigatons of carbon on Earth [1]. For example, the major capsid protein of the T4-like bacteriophage family is one of the most prevalent proteins in the biosphere [2]. Therefore, phages represent a major potential carbon source that bacteria may tap into. Furthermore, viruses are also a potential source of phosphorus [3].

No bacterium preying on viruses have been described even though bacterial extracellular proteases are able to degrade certain bacteriophages in anaerobic wastewater treatment plants, in pure cultures [4], and in soil [5]. In seawater, the only reported biotic pressure arises from marine ciliates that have been co-incubated with viruses and bacteria [6]. This observation is also supported by the recent discovery of viral DNA in free-living eukaryotic cells [7].

Here, we show that specific bacteria can indeed degrade T4 bacteriophages in situ, and we confirm this observation in pure culture.

\section{Materials and Methods}

\subsection{Preparation of the ${ }^{13} \mathrm{C}$-Labeled T4 Bacteriophages}

T4-phage particles labeled with ${ }^{13} \mathrm{C}$ were produced on Escherichia coli B cells (DSM 613) grown in $\mathrm{M} 9$ minimal medium with ${ }^{13} \mathrm{C}$-glucose as the sole carbon source. The $\mathrm{M} 9$ medium was prepared using M9, Minimal Salts, 5X (Sigma-Aldrich, St. Louis, MI, USA), by 
adding $\mathrm{MgSO}_{4}$ (Sigma-Aldrich) and $\mathrm{CaCl}_{2}$ (Sigma-Aldrich) at final concentrations of $1 \mathrm{mM}$ and D-Glucose at a final concentration of $10 \mathrm{~g} / \mathrm{L}$. Moreover, additional salts were added to favor phage adsorption (a solution of $\mathrm{CaCl}_{2} 0.5 \mathrm{M}$ and $\mathrm{MgCl}_{2} 1 \mathrm{M}$ diluted 1000 times in the culture medium). More precisely, starting from an E. coli stock of cells frozen in LB and glycerol, two successive overnight pre-cultures were grown in LB medium (LB broth, Fisher). Subsequently, $5 \times 20 \mathrm{~mL}$ of M9 minimal medium containing D-Glucose- ${ }^{13} \mathrm{C} 6$ as the sole carbon source $(10 \mathrm{~g} / \mathrm{L})$ were each inoculated with $20 \mu \mathrm{L}$ of the second E. coli preculture; approximately 1500 T4-phage particles (DSM 4505, in PFU) were added. Finally, $20 \mu \mathrm{L}$ of a solution containing $0.5 \mathrm{M} \mathrm{CaCl}_{2}$ and $1 \mathrm{M} \mathrm{MgCl}_{2}$ was also added in each case to favor phage adsorption.

After $30 \mathrm{~h}$ of incubation at $37^{\circ} \mathrm{C}$ under agitation, the $\mathrm{T} 4$ phage particles were collected: the cultures were centrifuged for $15 \mathrm{~min}$ at $5000 \times \mathrm{g}$ and at a temperature of $10^{\circ} \mathrm{C}$. The supernatants were collected and filtered with $0.22 \mu \mathrm{m}$ pore-sized PES filters (Millipore, Burlington, MA, USA). They were subsequently incubated overnight in 8\% w/v PEG 6000 and $0.5 \mathrm{M} \mathrm{NaCl}$ solution at $4{ }^{\circ} \mathrm{C}$ to precipitate viral particles. The supernatants were centrifuged at $20,000 \times \mathrm{g}$ for $30 \mathrm{~min}$ at $4{ }^{\circ} \mathrm{C}$. The pellets were suspended in $\mathrm{SM}$ buffer $\left(100 \mathrm{mM} \mathrm{NaCl}, 8 \mathrm{mM} \mathrm{MgSO}_{4}, 50 \mathrm{mM}\right.$ Tris $\mathrm{pH}$ 7.5) and were centrifuged once more at $20,000 \times g$ for $4 \mathrm{~h}$ at $4{ }^{\circ} \mathrm{C}$. The viral particles were finally suspended in $1.4 \mathrm{~mL}$ of SM buffer and were stored at $4{ }^{\circ} \mathrm{C}$ before use (Appendix $\mathrm{C}$ Figure $\mathrm{A} 3$ for details). To obtain unlabeled T4 phage particles, the same procedure was used, except unlabeled glucose was employed in the M9 minimal medium.

\subsection{Incubation of ${ }^{13} \mathrm{C}$-Labeled T4 Bacteriophages with Aerobic Sludge}

A $100 \mathrm{~mL}$ sample was taken from an aerobic wastewater treatment plant and was stabilized without the addition of substrate for one week at room temperature.

The T4 phages were incubated at $20^{\circ} \mathrm{C}$ with $200 \mu \mathrm{L}$ of the initial sample from the wastewater treatment plant under $50 \mathrm{rpm}$ agitation. The initial concentration in the ${ }^{13} \mathrm{C}$ bottle was $2.24 \times 10^{10} \mathrm{~T} 4$ phages in $5 \mathrm{~mL}$, i.e., $4.48 \times 10^{9} \mathrm{~T} 4$ phages $/ \mathrm{mL}$. The PFU titers of the obtained; ${ }^{13} \mathrm{C}$ - and unlabeled T4 stock solutions were determined on a bacterial lawn of $E$. coli cells (DSM 613) using the soft-agar overlay technique. More precisely, $5 \mu \mathrm{L}$ of T4 phage stock solutions and 10-fold serial dilutions of those solutions were plated on a soft layer containing $7.5 \mathrm{~g} / \mathrm{L}$ of Agar and E. coli cells (DSM 613) that had been pre-cultured in LB medium and in LB-Agar plates ( $15 \mathrm{~g} / \mathrm{L}$ of Agar, Sigma-Aldrich). After a short drying period, the Petri dishes were incubated at $37^{\circ} \mathrm{C}$ over $24 \mathrm{~h}$ in static conditions. The PFU titers were determined by counting the visible plaques and by calculating the concentration in the original stock solutions.

\subsection{DNA Extraction and $16 S$ rDNA Analysis}

The three samples (the initial sample from the wastewater treatment plant, the ${ }^{12} \mathrm{C}$ bottle after $24 \mathrm{~h}$ of incubation, and the ${ }^{13} \mathrm{C}$ bottle after $24 \mathrm{~h}$ of incubation) were used for ribosomal 16S DNA sequencing and analysis. After the addition of $3 \times 10^{5}$ copies of internal standard [8], bead beating lysed the microbial cells, and the DNA was purified using the ZR-96 Soil Microbe DNA kit according to the manufacturer's description (Zymo Research, Irvine, CA, USA). The V4-V5 region was amplified from purified genomic DNA with the primers 515F (5'-CTTTCCCTACACGACGCTCTTCCGATCTGTGYCAGCMGCCGCGGTA) and 928R (5'-GGAGTTCAGACGTGTGCTCTTCCGATCTCCCCGYCAATTCMTTTRAGT) using 30 amplification cycles with an annealing temperature of $65{ }^{\circ} \mathrm{C}$ (an amplicon of $510 \mathrm{bp}$, although length varies depending on the organisms). Because the Illumina MiSeq technology enables paired 300-bp reads, the ends of each read overlap and can be stitched together to generate extremely high-quality, full-length reads of the entire V4-V5 region in a single run. Single multiplexing was performed using a homemade $6 \mathrm{bp}$ index, which were added during a second PCR with 12 cycles using a forward primer (AATGATACGGCGACCACCGAGATCTACACTCTTTCCCTACACGAC) and a reverse primer (CAAGCAGAAGACGGCATACGAGAT-index-GTGACTGGAGTTCAGACGTGT). The 
resulting PCR products were purified and were loaded onto the Illumina MiSeq cartridge according to the manufacturer's instructions. The quality of the run was checked internally using PhiX control as recommended by manufacturer, and then each pair-end sequence was assigned to its sample with the help of the previously integrated index. Each pair-end sequence was assembled using Flash software [9] using at least a 10bp-overlap between the forward and reverse sequences. The absence of contamination was checked with a negative control during the PCR (water as the template). The quality of the stitching procedure was controlled using four bacterial samples that are run routinely in the sequencing facility in parallel to the current samples.

The resulting sequences were analyzed using the DADA2 pipeline (maxN $=0$, truncQ $=2$, trimLeft $=c(17,17)$, pool $=$ "pseudo") [10] with the Silva 138 database [11]. Chimeras were removed by means of the DADA2 using the consensus method. Normalisation was performed using the internal standard, and the total bacterial 16S rDNA was measured using qPCR (see below).

\subsection{Detailed Calculations of the ${ }^{13} \mathrm{C}$ Mass Balance}

This paragraph explains the mass balance in detail. For a simpler explanation, here, we will focus on the calculations for the Amplicon Sequence Variant ASV1 (because it corresponds to the Aeromonas_isolate_007 that we used to confirm the consumption of T4 phages in pure culture).

STEP1: using qPCR, we determined the absolute abundance of total bacteria in the ${ }^{13} \mathrm{C}$ bottle at the beginning of the experiment and at the end of the experiment. This could be conducted because we spiked $3 \times 10^{5}$ copies of a synthetic DNA standard to $200 \mu \mathrm{L}$ of the initial sample [8], which we extracted immediately and quantified using 16S the universal primers 515F-928R with the Illumina adapters. We also quantified the spiked synthetic DNA standard by qPCR [8]. The ratio between the internal standard and the total bacterial $16 \mathrm{~S}$ rDNA indicates the number of $16 \mathrm{~S}$ rDNA copies in the extraction tube from the ${ }^{13} \mathrm{C}$ bottle independently from the DNA recovery yield, which was estimated to be $2.35 \times 10^{8}$ copies of $16 \mathrm{~S}$ rDNA. For an accurate mass balance, we also considered the fact that $240 \mu \mathrm{L}$ were removed for the PFU measurements during the experiment, so we estimated that $2.47 \times 10^{8}$ copies of $16 \mathrm{~S}$ rDNA would have been present at the end of the experiment in the ${ }^{13} \mathrm{C}$ bottle if no sampling had been performed.

STEP2: Using the absolute abundance of total 16S rDNA from STEP1 and 16S barcoding, we converted the proportion of each ASV into the absolute abundance of each ASV at the beginning and at the end of the experiment, thereby estimating the number of $16 S$ rDNA copies produced during the experiment for each ASV. ASV1 was undetectable in the 3748 sequences of $16 \mathrm{~S}$ rRNA genes obtained at the beginning of the experiment. At the end, 303 sequences out of 3578 (i.e., 8\%) belonged ASV1, while 3578 sequences correspond to $2.47 \times 10^{8}$ copies of $16 \mathrm{~S}$ rDNA, so we estimated that we had $2.47 \times 10^{8} \times$ $303 / 3578=2.09 \times 10^{7}$ copies of Aeromonas $16 \mathrm{~S}$ rDNA at the end of the experiment. For the two instances where the final 16SrDNA abundances were lower than the initial 16S rDNA abundances (possibly due to part of the population dying combined with another part showing small growth), we neglected the contribution of these ASVs to the ${ }^{13} \mathrm{C}$ mass balance.

STEP3: We converted the increase in the $16 \mathrm{~S}$ rDNA from STEP2 into the number of cells using a database that associates a $16 \mathrm{~S}$ rDNA copy number with each bacterial genus [12] This database associated ASV1 with 10 copies of $16 \mathrm{~S}$ rDNA, so the $2.09 \times 10^{7}$ copies of $16 \mathrm{~S}$ rDNA that were estimated in STEP2 actually correspond to $2.09 \times 10^{6}$ Aeromonas cells. It should be noted that the estimated generation time is within a realistic range: ASV 1 was undetectable at $\mathrm{t}_{0}$, so if only 1 cell of ASV 1 (Aeromonas sp.) was present at the beginning of the experiment, 22 generations would have been needed in the course of the experiment to produce $2 \times 10^{6}$ cells, i.e., 62 min per generation. If ASV 1 was just below the detection limit $\left(\left(1 / 3748 \times 9.78 \times 10^{7}\right) / 10=2600\right)$, the same rationale estimates an average growth rate of $125 \mathrm{~min}$ per generation. 
STEP4: We converted the number of cells to their carbon content. It should be noted that $30 \mathrm{fg}$ of carbon was measured for the dried Aeromonas cells using a Leco CHN analyzer [12], but we assumed the same value for every ASV because the cellular carbon content varied between 20 and $40 \mathrm{fg}$, depending on the bacterial species. Assuming that each cell contained $30 \mathrm{fg}$ of carbon, we converted the number of cells produced during the course of the experiment to a total carbon reservoir at the end of the experiment $\left({ }^{13} \mathrm{C}+\right.$ $\left.{ }^{12} \mathrm{C}\right)$. Aeromonas had $2.09 \times 10^{7}$ cells at the end and a negligible amount at the beginning (undetectable). We then estimated the amount of total carbon that was captured by the growth of ASV1. For example, $2.09 \times 10^{7}$ Aeromonas cells translate into $6.28 \times 10^{-8} \mathrm{~g}$ of total carbon content.

STEP5: Using the shifts in buoyant density between the ${ }^{12} \mathrm{C}$ - and the ${ }^{13} \mathrm{C}$-bottles, we estimated the labeling level of each ASV so that we could estimate their contribution to the ${ }^{13} \mathrm{C}$ mass balance. We compared the buoyant density of each ASV in the ${ }^{13} \mathrm{C}$ bottle to the density of in the ${ }^{12} \mathrm{C}$ bottle by fitting a normal curve to the absolute numbers of the $16 \mathrm{~S}$ rRNA genes that were detected in each fraction. Since we measured the density of each fraction by refractometry, the mean of the normal curve is the best estimate of the actual buoyant density of the ASV. For example, the 16S DNA of ASV1 have a mean density of 1.72 in the ${ }^{12} \mathrm{C}$ bottle and 1.75 in the ${ }^{13} \mathrm{C}$ bottle with good fits ( $\mathrm{R}^{2}=0.98$ and 0.89$)$. As mentioned in the text, ASV2 (identified as Tolumonas sp.) was not abundant enough in the ${ }^{12} \mathrm{C}$ bottle to fit a normal curve on its distribution across the gradient, so we used its theoretical density based on its GC content (which shows a 15\% error). The shift between the ${ }^{12} \mathrm{C}$ - and ${ }^{13} \mathrm{C}$-densities was converted into a percentage of ${ }^{13} \mathrm{C}$ by dividing by 0.036 [13]. The labeling level of ASV1 was $(1.75-1.72) / 0.036=85 \%$.

STEP6: To complete the mass balance of the ${ }^{13} \mathrm{C}$-atoms of the labeled $\mathrm{T} 4$ phages, we multiplied the total carbon content of each species by its labeling level. For example, ASV1 (Aeromonas sp.) represents $6.28 \times 10^{-8} \times 0.85=5.33 \times 10^{-8} \mathrm{~g}$ of carbon.

STEP7: To estimate the mass of the carbon needed to account for the carbon content observed for each species, we assumed that the carbon use efficiency for each ASV was 33\% (see pure culture experiment). It should be noted that we measured the yield for ASV1, and we then we assumed the same yield for every ASV. Once corrected by the carbon use efficiency (i.e., the bacterial yield), the estimation of the ${ }^{13} \mathrm{C}$ needed by each species was compared to the $3.2 \times 10^{-6} \mathrm{~g}$ of ${ }^{13} \mathrm{C}$ incorporated in the $2.28 \times 10^{10}{ }^{13} \mathrm{C}$-labeled T4 phages (since each T4 viral particle contained $1.49 \times 10^{-16} \mathrm{~g} \mathrm{C}$, and we assumed that they were $100 \%$ labeled with ${ }^{13} \mathrm{C}$ because of their production method). For example, we estimated $2.09 \times 10^{6}$ newly synthesized ASV1 cells, which accounted for $6.28 \times 10^{-8} \mathrm{~g}{ }^{13} \mathrm{C}$ and therefore corresponded to $5 \%$ of the ${ }^{13} \mathrm{C}$ atoms that were initially present. Adding the contributions of the nine most-labeled ASVs accounted for $41 \%$ of the initial mass of ${ }^{13} \mathrm{C}$.

\subsection{Isolation of Aeromonas_Isolate_007 and Subsequent Experiments}

Following the stable isotope probing experiment, we could isolate a strain of Aeromonas sp. (corresponding to the amplicon sequence variant ASV1) from the initial sample using the Aeromonas Isolation Agar medium (Sigma 17118) with ampicillin since Aeromonads are resistant to ampicillin. Therefore, we could confirm that Aeromonas sp. was indeed able to assimilate the carbon of the T4 phages. Furthermore, we could show that Aeromonas could use T4 phages as a carbon and nitrogen source, with a 33\% yield, and we also completed a scan the genome of Aeromonas_isolate_007 for the putative mechanisms by which Aeromonas could capture and digest the T4 phage proteins and transfer the generated peptides into the intracellular space.

We incubated 50 Aeromonas cells with $10^{11} \mathrm{~T} 4$ phages in $1 \mathrm{~mL}$ of SM buffer without gelatin $\left(100 \mathrm{mM} \mathrm{NaCl}, 8 \mathrm{mM} \mathrm{MgSO}_{4}, 50 \mathrm{mM}\right.$ Tris $\left.\mathrm{HCl}\right)$ at $20^{\circ} \mathrm{C}$ to confirm the consumption of T4 phages by Aeromonas sp. 


\subsection{Sequencing of Aeromonas_Isolate_007}

Aeromonas DNA was fragmented by sonication and sequencing adaptors were ligated. A total of eight cycles of PCR were applied to amplify the libraries. Library quality was assessed using an Advanced Analytical Fragment Analyzer, and the libraries were quantified by QPCR using the Kapa Library Quantification Kit. DNA-seq experiments were performed on an Illumina Miseq using a paired-end read length of $2 \times 300 \mathrm{pb}$ with the Illumina MiSeq Reagent Kits v3. The sequences were quality trimmed with fastp v0.20.05, assembled by Spades v3.14.16 after removing the residual phiX by using bowtie2 v2.3.5.17 and filtering scaffolds smaller than the right insert size quantile $525 \mathrm{nt}$ and coverage smaller than $50 \times$.

\section{Results}

\subsection{Stable Isotope Probing Experiment with T4 Bacteriophage}

\subsubsection{T4 Phages Support Bacterial Growth}

To search for bacteriophage consumption activity, we chose wastewater because it contains a high bacterial diversity, high nutrient degradation/turnover rate, and a high microbial metabolic rate. In this work, the stable isotope probing method was applied by adding $2.2 \times 10^{10}{ }^{13} \mathrm{C}$-labelled T4 phages to $200 \mu \mathrm{L}$ of sludge corresponding to $10^{8}$ bacteria cells. The enumerated T4 phages decreased by $99 \%$ in $24 \mathrm{~h}$ (Table 1), at which point the bacterial $16 \mathrm{~S}$ rDNA genes were analyzed.

Table 1. Decrease of the free ${ }^{13} \mathrm{C}$ and ${ }^{12} \mathrm{C}$ bacteriophages by PFU of the supernatant. We indicate the absolute numbers of phages and their percentages compared to $t 0$.

\begin{tabular}{ccccc}
\hline $\begin{array}{c}\text { Time } \\
(\text { min) }\end{array}$ & $\begin{array}{c}\text { T4 Phages } \\
\text { in }{ }^{12} \text { C Bottle }\end{array}$ & $\begin{array}{c}\text { T4 Phages } \\
\text { in }{ }^{13} \text { C Bottle }\end{array}$ & $\begin{array}{c}\text { T4 Phages } \\
\text { in }{ }^{12} \text { C Bottle }\end{array}$ & $\begin{array}{c}\text { T4 Phages } \\
\text { in }{ }^{13} \text { C Bottle }\end{array}$ \\
\hline 0 & $2.8 \times 10^{10}$ & $2.2 \times 10^{10}$ & $100 \%$ & $100 \%$ \\
\hline 24 & $5.2 \times 10^{8}$ & $9.4 \times 10^{8}$ & $1.9 \%$ & $4.2 \%$ \\
\hline 122 & $2.6 \times 10^{7}$ & $4.1 \times 10^{8}$ & $0.9 \%$ & $1.8 \%$ \\
\hline 445 & $3.2 \times 10^{7}$ & $3.3 \times 10^{8}$ & $1.2 \%$ & $1.5 \%$ \\
\hline 1375 & $5 \times 10^{2}$ & $5.7 \times 10^{5}$ & $0 \%$ & $0 \%$ \\
\hline
\end{tabular}

The decrease of T4 phages is concomitant with a 2.35-fold increase of the 16S rDNA genes (Table 2). Indeed, the comparison of the $16 \mathrm{~S}$ and internal standard qPCR curves indicates that the initial sample contained $1.798^{23.462} / 1.828^{13.215}=326$-fold more bacterial $16 \mathrm{~S}$ rDNA copies than the internal standard, so the tube contained $3 \times 10^{5} \times 326=$ $9.78 \times 10^{7}$ copies of bacterial $16 \mathrm{~S}$ at the beginning of the experiment. At the end of the experiment, a comparison of the $16 \mathrm{~S}$ and internal standard qPCR curves indicates that bacterial $16 \mathrm{~S}$ rDNA were 783fold more abundant than the spiked synthetic standard, leading to an estimated $2.35 \times 10^{8}$ copies of bacterial $16 \mathrm{~S}$ rDNA genes in the ${ }^{13} \mathrm{C}$ bottle. For an accurate mass balance, we also considered the fact that $240 \mu \mathrm{L}$ were taken out for PFU measurements during the experiment, so we estimated that $2.47 \times 10^{8}$ copies of $16 \mathrm{~S}$ rDNA would have been present at the end of the experiment in the ${ }^{13} \mathrm{C}$ bottle if no sampling had been performed. Since we used the LinReg software, we also accounted for the slight individual variations in qPCR efficiency, which were between 80 and $84 \%$ for the internal standard and between 80 and $82 \%$ for the bacterial $16 \mathrm{~S}$ rRNA genes, respectively. In total, we estimated a global biomass increase of 2.35-fold. This global increase regroups the ASVs that were initially abundant and that have a tendency towards slight growth with the ASVs that are initially rare and grow massively. 
Table 2. Quantification of the bacterial density with the internal standard at the beginning and at the end of the experiment.

\begin{tabular}{|c|c|c|c|c|c|}
\hline Sample Name & Primers & Efficiency & Cycle Threshold & Spiked Internal Standard & 16S rDNA \\
\hline \multirow{2}{*}{ Initial sample } & Internal standard & $79.8 \%$ & 23.462 & \multirow{2}{*}{$3 \times 10^{5}$ copies } & \multirow{2}{*}{$9.78 \times 10^{7}$ copies } \\
\hline & V4V5 & $82.8 \%$ & 13.215 & & \\
\hline \multirow{2}{*}{ Final ${ }^{13} \mathrm{C}$ sample } & Internal standard & $80.1 \%$ & 14.133 & \multirow{2}{*}{$3 \times 10^{5}$ copies } & \multirow{2}{*}{$2.35 \times 10^{8}$ copies } \\
\hline & V4V5 & $84.5 \%$ & 24.461 & & \\
\hline
\end{tabular}

The bacterial growth concomitant to the decrease of $\mathrm{T} 4$ phages changes the composition of the microbial community: In particular ASV1 and ASV2 strongly increased (Figure 1 and Table 3), suggesting that these bacterial species are more adapted to the consumption of bacteriophages, assuming that any other substrates were consumed during the stabilization period before the experiment.

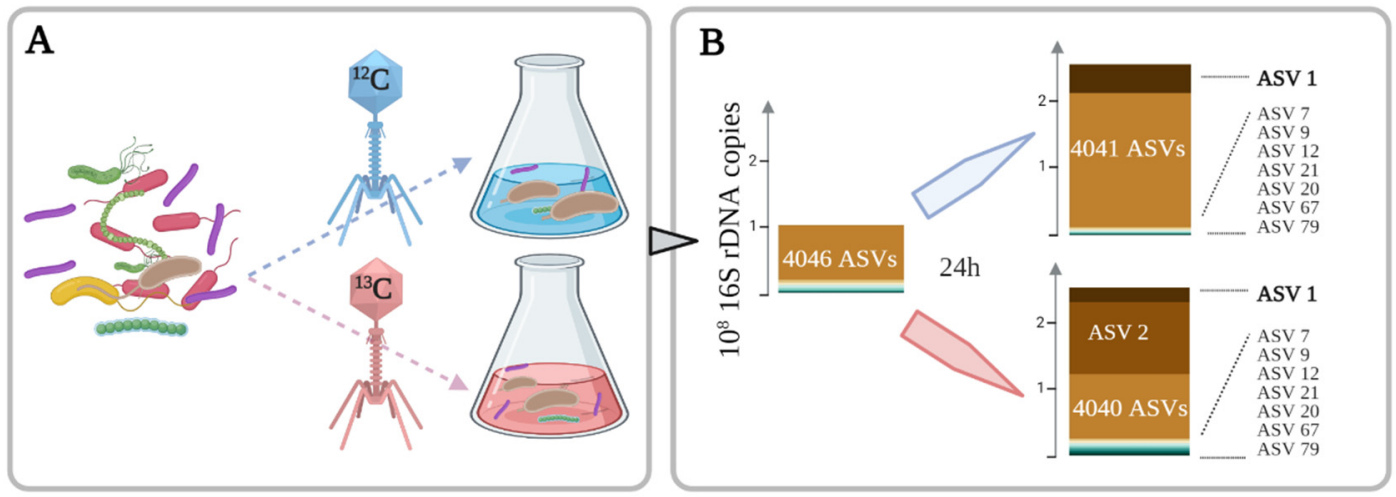

Figure 1. Bacterial growth on T4 phages. (A); Identification of ${ }^{13} \mathrm{C}$-labeled bacteria: the ${ }^{13} \mathrm{C}$-labeled $\mathrm{T} 4$ (red) were incubated with a microbial community of a wastewater treatment plant in the same conditions as the ${ }^{12} \mathrm{C}$ control (blue). (B); Bacteria present in each sample: the bar plots show the growth of each ASVs based on the 16S rDNA copies, detailing the nine bacteria assimilating T4 phages.

Table 3. Taxonomic affiliation of the ASVs that are significantly labeled with ${ }^{13} \mathrm{C}$. This table indicates the taxonomy of the labeled ASV performed by DADA2 with the Silva138 dataset. The taxonomy was also checked by means of blasting on the NCBI database.

\begin{tabular}{ccccc}
\hline seq_ID.x & Class & Order & Family & Genus \\
\hline ASV 2 & Gammaproteobacteria & Aeromonadales & Aeromonadaceae & Tolumonas \\
ASV 1 & Gammaproteobacteria & Aeromonadales & Aeromonadaceae & Aeromonas \\
ASV 12 & Ignavibacteria & Ignavibacteriales & PHOS-HE36 & NA \\
ASV 21 & Ignavibacteria & Ignavibacteriales & PHOS-HE36 & NA \\
ASV 79 & Bacteroidia & Chitinophagales & Saprospiraceae & Haliscomenobacter \\
ASV 20 & Bacteroidia & Chitinophagales & Saprospiraceae & NA \\
ASV 67 & Anaerolineae & Ardenticatenales & NA & NA \\
ASV 7 & Gammaproteobacteria & Burkholderiales & Rhodocyclaceae & NA \\
ASV 9 & Gammaproteobacteria & Burkholderiales & Rhodocyclaceae & Dechloromonas \\
\hline
\end{tabular}

\subsubsection{Increase of DNA Density of 9 Microbial Species after $24 \mathrm{~h}$}

The assimilation of phages by specific members of the bacterial community is confirmed by the increase in the DNA density of nine bacterial species as they assimilate the ${ }^{13} \mathrm{C}$ labeled bacteriophages (Figure 2). About $41 \%$ of the ${ }^{13} \mathrm{C}$ atoms initially present in the $\mathrm{T} 4$ phages were accounted for in the bacterial biomass. However, only 9 out of the $4046 \mathrm{mi}-$ crobial species—or more accurately, the Amplicon Sequence Variant (ASVs)—were labelled by the ${ }^{13} \mathrm{C}$ initially contained in the $\mathrm{T} 4$ phages, thus suggesting that the incorporation of $\mathrm{T} 4$ 
phage is not a widespread ability. This incorporation is in agreement with the 2.35 -fold growth and the disappearance of the T4 phages.

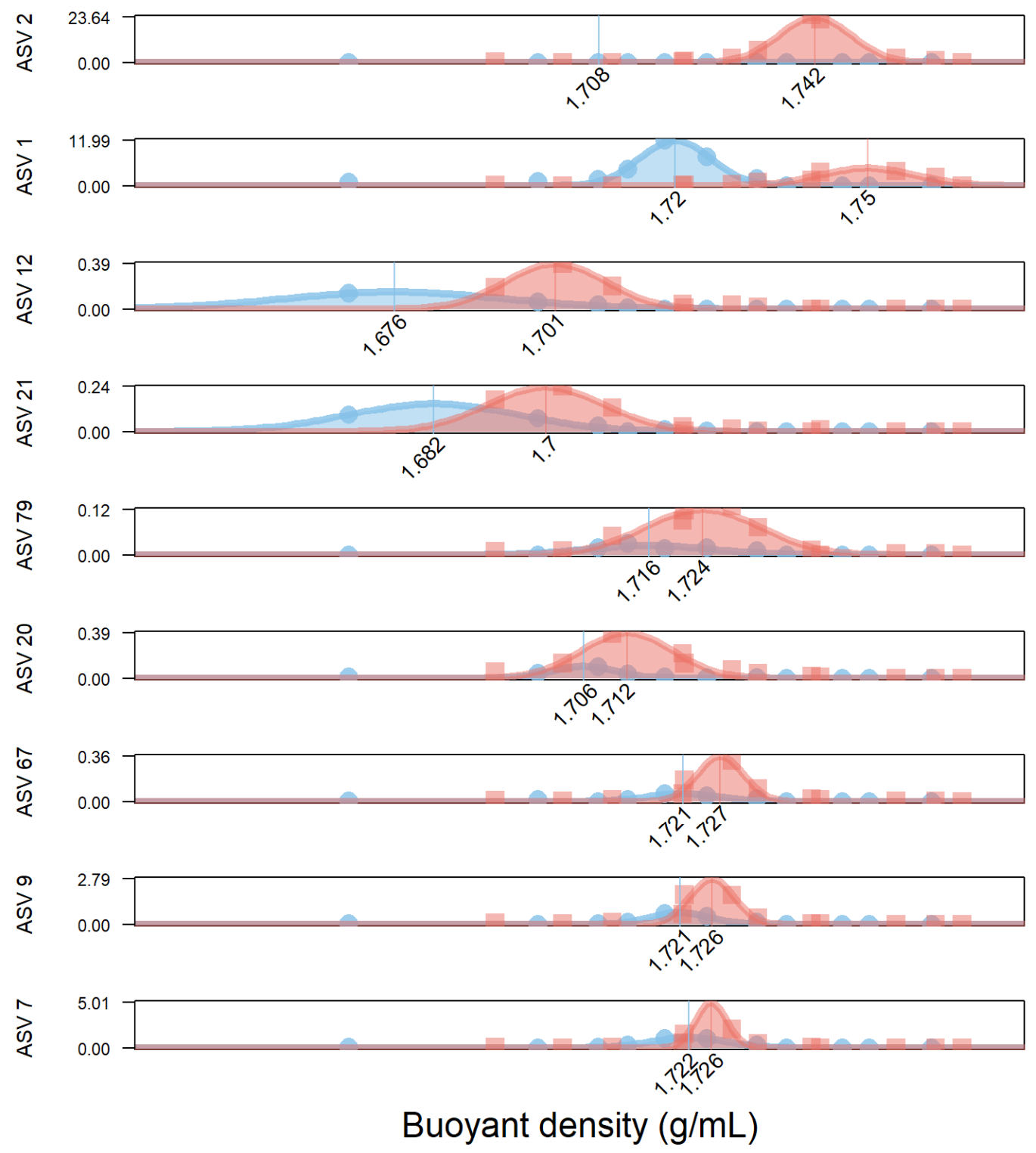

Figure 2. The amount of DNA for the top nine ASVs (in $\mathrm{ng}$ ) is plotted against the density of the Cesium gradient (in $\mathrm{g} / \mathrm{mL}$ ). The blue color is in the control bottle. The red color indicates the amount of DNA in the bottle supplemented with $3.2 \mu \mathrm{g}$ of ${ }^{13} \mathrm{C}$ in the ${ }^{13} \mathrm{C}$-labeled $\mathrm{T} 4$ bacteriophages. The dots indicate the actual measures performed after $24 \mathrm{~h}$, i.e., the amount of DNA of each ASV (Qbit was combined with the 16S rDNA sequencing) in each fraction, the density of which was measured by means of refractometry. The lines indicate the Gaussian distributions to accurately estimate the mean buoyant density. The mean buoyant density of ASV 2 (Tolumonas sp.) was estimated with the theoretical value in the ${ }^{12} \mathrm{C}$ bottle, as ASV2 did not grow sufficiently in that bottle to fit a reliable Gaussian fit. The pie charts indicate the ratios of the nine ${ }^{13} \mathrm{C}$-labeled ASV in the ${ }^{13} \mathrm{C}$ and ${ }^{12} \mathrm{C}$ bottles after $24 \mathrm{~h}$, and their proportion in the initial sample is reported in the $\mathrm{X}$ axis. For example, the pie of Aeromonas is roughly balanced because ASV 1 (Aeromonas sp.) represents $19 \%$ and $8 \%$ in the $12 \mathrm{C}$ and $13 \mathrm{C}$ bottles, respectively. In contrast, ASV 2 (Tolumonas sp.) only grew substantially in the ${ }^{13} \mathrm{C}$ bottle (red).

The two main degraders of the T4 phages were ASV1 (identified as Aeromonas sp.) and ASV2 (identified as Tolumonas sp.), which accounted for $5 \%$ and $29 \%$ of the ${ }^{13} \mathrm{C}$ atoms found in the bacterial biomass, respectively. Both belong to the Aeromonadaceae family and exhibit strong growth rates. Indeed, both rose from undetectable levels to $51 \%$ of the biomass, while the density of their DNA increased because they incorporated ${ }^{13} \mathrm{C}$ atoms 
from the isotopically labelled T4 phages. For example, the $2 \times 10^{6}$ Aeromonas cells present after $24 \mathrm{~h}$ contained $85 \%$ of the ${ }^{13} \mathrm{C}$ atoms in their DNA, the density of which shifted from $1.72 \mathrm{~g} / \mathrm{mL}$ to $1.75 \mathrm{~g} / \mathrm{mL}$ in the bottle with the ${ }^{13} \mathrm{C}$-labeled T4 phages. The $16 \mathrm{~S}$ rRNA sequences assigned to Aeromonas represented $19 \%$ and $8 \%$ of the total reads in the ${ }^{12} \mathrm{C}$ and the ${ }^{13} \mathrm{C}$ bottles, respectively, thus revealing a consistent growth from initially undetectable levels (Figure 1) in addition to the increase of their DNA density (Figure 2).

In addition to the Aeromonadaceae family, two species (ASV12 and 21) belonging to the Ignavibacteriales PHOS-HE36 family, although labelled with medium strength (49 and 71\%) and negligible growth ( 0 and $5.87 \times 10^{6}$ synthetized cells, respectively), still gathered $5 \%$ of the ${ }^{13} \mathrm{C}$ atoms (Table 4). The last five species with significant DNA density shifts (ASV7, $9,20,67$, and 79 ) accounted for the remaining $1 \%$ of the ${ }^{13} \mathrm{C}$ atoms, but their labelling level being below $25 \%$ may have resulted from indirect labelling.

Table 4. ${ }^{13} \mathrm{C}$ mass balance of the isotopically labeled $\mathrm{T} 4$ bacteriophages. This table indicates the rationale for the ${ }^{13} \mathrm{C}$ mass balance following the steps described above. For example, ASV 1 (Aeromonas sp.) represents $8 \%$ of the $2.47 \times 10^{8} 16 \mathrm{~S}$ rDNA copies found at the end of the experiment, which represents $5 \%$ of the total amount of $13 \mathrm{C}$ present in the initial $\mathrm{T} 4$ phages because the $30 \mathrm{fgC}$-cells labeled at $85 \%$ needed $5.3 \times 10^{-8} \mathrm{~g}$ of $13 \mathrm{C}$ if we consider a $33 \%$ yield.

\begin{tabular}{|c|c|c|c|c|c|c|c|c|c|c|}
\hline & Description & ASV 1 & ASV 2 & ASV 7 & ASV 9 & ASV 12 & ASV 20 & ASV 21 & ASV 67 & ASV 79 \\
\hline \multirow{2}{*}{$\vec{c}$} & $\begin{array}{l}\text { Absolute number of } \\
\text { 16S rDNA copies in } \\
\text { the initial sample }\end{array}$ & & & & & $9.78 \times 10^{7}$ & & & & \\
\hline & $\begin{array}{l}\text { Absolute number of } \\
16 S \text { rDNA copies in } \\
\text { the final sample }\end{array}$ & & & & & $2.47 \times 10^{8}$ & & & & \\
\hline \multirow{7}{*}{ 商. } & $\begin{array}{c}\text { Counts in the initial } \\
\text { sample } \\
\text { (out of } 3748 \\
\text { sequences) }\end{array}$ & 0 & 0 & 148 & 132 & 197 & 123 & 0 & 46 & 53 \\
\hline & $\begin{array}{l}\text { Counts in the final } \\
{ }^{13} \mathrm{C} \text { sample } \\
\text { (out of } 3578 \\
\text { sequences) }\end{array}$ & 303 & 1545 & 37 & 62 & 52 & 55 & 55 & 41 & 55 \\
\hline & $\begin{array}{c}\text { Relative initial } \\
\text { abundance of 16S } \\
\text { rDNA of each ASV }\end{array}$ & $0 \%$ & $0 \%$ & $4 \%$ & $4 \%$ & $5 \%$ & $3 \%$ & $0 \%$ & $1 \%$ & $1 \%$ \\
\hline & $\begin{array}{c}\text { Relative final } \\
\text { abundance of 16S } \\
\text { rDNA of each ASV }\end{array}$ & $8 \%$ & $43 \%$ & $1 \%$ & $2 \%$ & $1 \%$ & $2 \%$ & $2 \%$ & $1 \%$ & $2 \%$ \\
\hline & $\begin{array}{c}\text { Absolute number of } \\
\text { 16S rDNA copies in } \\
\text { the initial sample of } \\
\text { each ASV }\end{array}$ & 0 & 0 & $3.86 \times 10^{6}$ & $3.44 \times 10^{6}$ & $5.14 \times 10^{6}$ & $3.21 \times 10^{6}$ & 0 & $1.20 \times 10^{6}$ & $1.38 \times 10^{6}$ \\
\hline & $\begin{array}{c}\text { Absolute number of } \\
\text { 16S rDNA copies in } \\
\text { the final sample of } \\
\text { each ASV }\end{array}$ & $2.09 \times 10^{7}$ & $1.07 \times 10^{8}$ & $2.55 \times 10^{6}$ & $4.28 \times 10^{6}$ & $3.59 \times 10^{6}$ & $3.80 \times 10^{6}$ & $3.80 \times 10^{6}$ & $2.83 \times 10^{6}$ & $3.80 \times 10^{6}$ \\
\hline & $\begin{array}{l}\text { Number of newly } \\
\text { synthetized } 16 S \\
\text { copies }\end{array}$ & $2.09 \times 10^{7}$ & $1.07 \times 10^{8}$ & 0 & $8.36 \times 10^{5}$ & 0 & $5.87 \times 10^{5}$ & $3.80 \times 10^{6}$ & $1.63 \times 10^{6}$ & $2.41 \times 10^{6}$ \\
\hline \multirow{2}{*}{$\sum_{\infty}^{\infty}$} & $\begin{array}{c}\text { Number of } 16 \mathrm{~S} \text { rDNA } \\
\text { copies per genome of } \\
\text { each ASV [14] }\end{array}$ & 10 & 10 & 4 & 4 & 1 & 2 & 1 & 2 & 2 \\
\hline & $\begin{array}{l}\text { Number of newly } \\
\text { synthetized cells of } \\
\text { each ASV }\end{array}$ & $2.09 \times 10^{6}$ & $1.07 \times 10^{7}$ & 0 & $2.09 \times 10^{5}$ & 0 & $2.94 \times 10^{5}$ & $3.80 \times 10^{6}$ & $8.15 \times 10^{5}$ & $1.21 \times 10^{6}$ \\
\hline \multirow{2}{*}{ 索 } & $\begin{array}{l}\text { Carbon content } \\
\quad(\mathrm{g} / \text { cell })\end{array}$ & & & & & $3.00 \times 10^{-14}$ & & & & \\
\hline & $\begin{array}{l}\text { Total Carbon content } \\
\text { in each ASV }(\mathrm{g})\end{array}$ & $6.28 \times 10^{-8}$ & $3.20 \times 10^{-7}$ & 0 & $6.27 \times 10^{-9}$ & 0 & $8.81 \times 10^{-9}$ & $1.14 \times 10^{-7}$ & $2.45 \times 10^{-8}$ & $3.62 \times 10^{-8}$ \\
\hline
\end{tabular}


Table 4. Cont.

\begin{tabular}{|c|c|c|c|c|c|c|c|c|c|c|}
\hline & Description & ASV 1 & ASV 2 & ASV 7 & ASV 9 & ASV 12 & ASV 20 & ASV 21 & ASV 67 & ASV 79 \\
\hline \multirow{6}{*}{ 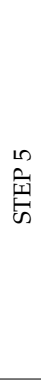 } & $\begin{array}{l}\text { Mean } 12 \mathrm{C} \text { density } \\
(\mathrm{g} / \mathrm{mL})\end{array}$ & 1.72 & 1.7 & 1.72 & 1.72 & 1.68 & 1.71 & 1.68 & 1.72 & 1.72 \\
\hline & $\underset{\left(\mathrm{R}^{2}\right)}{\text { Goodness_in_lit }{ }^{12} \mathrm{C}}$ & 0.98 & 0.4 & 0.99 & 0.97 & 0.99 & 0.97 & 0.98 & 0.88 & 0.89 \\
\hline & $\begin{array}{c}\text { Mean corrected }{ }^{12} \mathrm{C} \\
\text { density }\end{array}$ & 1.72 & 1.71 & 1.72 & 1.72 & 1.68 & 1.71 & 1.68 & 1.72 & 1.72 \\
\hline & Mean ${ }^{13} \mathrm{C}$ density & 1.75 & 1.74 & 1.73 & 1.73 & 1.7 & 1.71 & 1.7 & 1.73 & 1.72 \\
\hline & $\underset{\left(\mathrm{R}^{2}\right)}{\operatorname{Good}{ }^{2}{ }^{13} \mathrm{C}}$ & 0.89 & 0.99 & 0.9 & 0.89 & 0.98 & 0.93 & 0.99 & 0.94 & 0.94 \\
\hline & Labeling Level (\%) & $85 \%$ & $95 \%$ & $10 \%$ & $14 \%$ & $71 \%$ & $19 \%$ & $49 \%$ & $16 \%$ & $23 \%$ \\
\hline 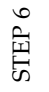 & $\begin{array}{c}{ }^{13} \mathrm{C} \text { carbon content in } \\
\text { each ASV }(\mathrm{g})\end{array}$ & $5.3 \times 10^{-8}$ & $3.0 \times 10^{-7}$ & 0 & $8.8 \times 10^{-10}$ & 0 & $1.7 \times 10^{-9}$ & $5.6 \times 10^{-8}$ & $3.9 \times 10^{-9}$ & $8.3 \times 10^{-9}$ \\
\hline \multirow{3}{*}{$\hat{\hat{n}}$} & $\begin{array}{l}\text { Carbon use efficiency } \\
\text { (i.e., Bacterial yield) }\end{array}$ & & & & & 0.33 & & & & \\
\hline & $\begin{array}{l}\text { Contribution to the } \\
{ }^{13} \mathrm{C} \text { mass balance (out } \\
\text { of the } 3.2 \mu \mathrm{g} \text { of }{ }^{13} \mathrm{C} \text { in } \\
\text { the bacteriophages) }\end{array}$ & $5 \%{ }^{1}$ & $29 \%^{1}$ & $0 \%^{1}$ & $0 \%{ }^{1}$ & $0 \%$ & $0 \%$ & $5 \%$ & $0 \%$ & $1 \%$ \\
\hline & ${ }^{13} \mathrm{C}$ mass balance & & & & & $41 \%$ & & & & \\
\hline
\end{tabular}

$1,83 \%$ of the predation of T4 phages is due to Gammaproteobacteria, which also include E. coli, the natural host of T4 phages.

\subsection{Validation in a Pure Culture Experiment}

\subsubsection{Pure Culture with High Phages Concentrations}

To confirm the quality of Aeromonas sp. as a predator of T4 phages, an Aeromonasselective medium was used for retrieving an Aeromonas colony from the initial sludge. It is called Aeromonas_isolate_007 in the text below. The analysis of the whole genome confirmed that this isolate belongs to an intermediate clade between the Aeromonas media and Aeromonas rivipollensis species and that it has 10 copies of $16 \mathrm{~S}$ rDNA based on the coverage ratio. Aeromonas_isolate_007 was incubated with T4 phages only as a substrate. Starting with 50 resting bacterial cells, the population reached $1.63 \times 10^{8}$ cells after $24 \mathrm{~h}$ at $20{ }^{\circ} \mathrm{C}$ while consuming $10^{11} \mathrm{~T} 4$ phages (Figure 3). No growth was observed when the T4 phages were absent from the SM buffer, and no degradation was observed when the bacterial cells were absent.
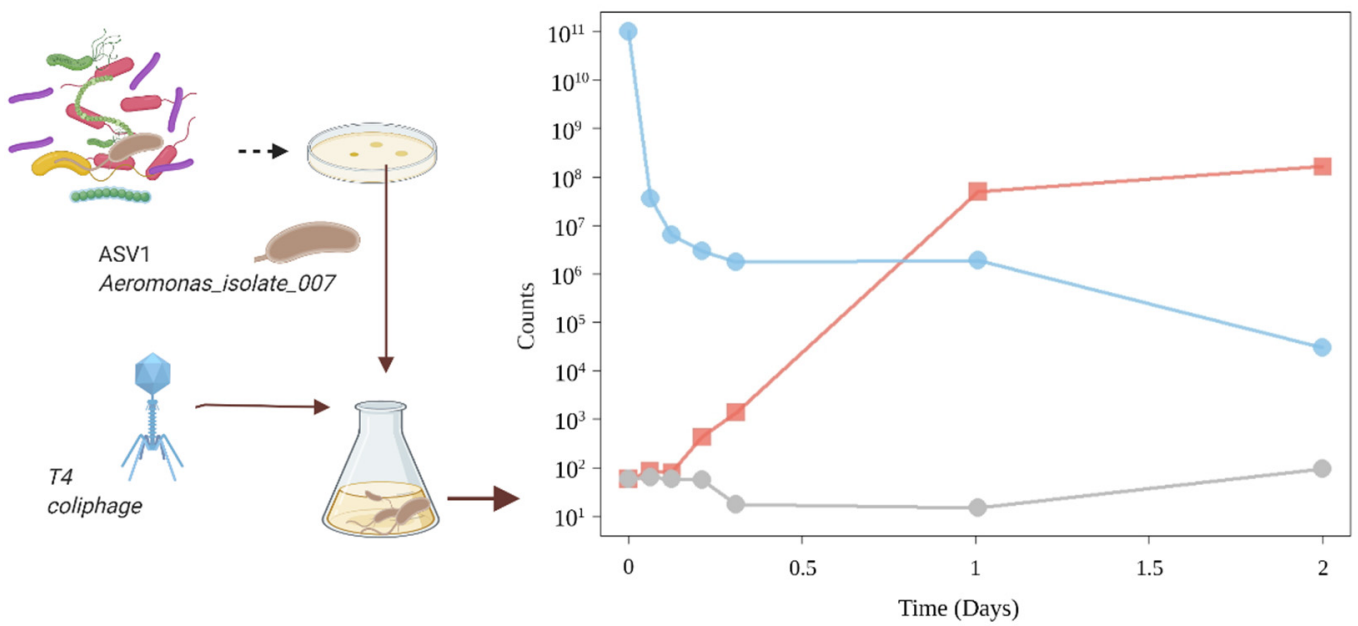

Figure 3. Aeromonas sp. growth on T4 phages: Aeromonas_isolate_007 isolated on the Aeromonas Isolation Agar medium grew on T4 phages as the sole carbon and nitrogen source. When a few Aeromonas cells were incubated with $10^{11} \mathrm{~T} 4$ phages, the colony forming units (red) increased while the plaque-forming units (blue) decreased. The Aeromonas cell control in SM buffer without phages (grey) confirms that Aeromonas cannot use the Tris from the SM buffer as a carbon source. 


\subsubsection{Pure Culture with Low Phages Concentrations}

Aeromonas sp. could also capture T4 phages when their concentrations were comparable with environmental conditions: $7 \times 10^{4} \mathrm{~T} 4$ phages $/ \mathrm{mL}$ decreased to $2 \times 10^{3} \mathrm{~T} 4$ phages $/ \mathrm{mL}$ when incubated with Aeromonas_isolate_007 cells. No decrease in the T7 phages have been observed in similar experiments where the T4 phages were replaced by T7 phages (data not shown).

\subsubsection{Sequencing Aeromonas_Isolate_007}

Aeromonas_isolate_007 had a genome of 4,667,413 nt in 29 scaffolds with a N50 of $947,468 \mathrm{nt}$ and an average size of 160,945 nt. This represents 4172 genes, and the number of $16 \mathrm{~S}$ rRNA copies was estimated to be 10.89 with the coverage, which is in accordance with the Vetrovsky database. The whole genome sequencing of Aeromonas_isolate_007 by Illumina Miseq narrows down the phylogeny of the strain (Appendix A Figure A1) and offers suggestions with respect to degradative enzymes that may help bacteriophage digestion (Appendix A Figure A2).

\section{Discussion}

Aeromonas cells are widely distributed [15], including in wastewater treatment plants, where their abundance is around $0.1 \%$ [16].

Interestingly, Aeromonas cells have an S-layer [17] that is associated with lipopolysaccharides [18] and an outer membrane protein C (Appendix A Figure A2 and Appendix B Table A1), which are known to bind the T4 phages to the surface of E.coli cells [19]. Once captured at the surface, the phage is likely degraded by several extracellular enzymes, including DNase and protease [20]. For example, metallo- and serine-proteases found in Aeromonas are involved in the degradation of large molecules such as albumin, earning the nickname of "Jack-of-all-trades" due to this enzymatic versatility [21]. Finally, Aeromonas possesses transporters to uptake the resulting amino acids and peptides [21].

Bacterial predation on bacteriophages is rich in consequences because bacteriophages can control the abundance of specific bacterial species. Indeed bacteriophage decay is mainly considered abiotic via adhesion to particulate material, chemical inactivation, or degradation by solar radiation or passive grazing by flagellates [6]. Here, we showed that there might be a non-negligible fraction of phage degradation that could be due to low-abundant bacterial species.

Furthermore, the diversity in bacteriophages could be partly related to the presence of phage-specific bacterial predation. Indeed, the bacterial predators of T4 phages do not appear to consume T7 bacteriophages. Therefore, a rapid increase of a specific phage in the environment could be specifically controlled by a phage-eating bacterium, forming a killing-the-killer loop. This is especially true as the two main degraders in our experiment were initially undetectable. Therefore, the control of the T4 phages at the end of our experiment is likely to be more pronounced than at the beginning of the experiment, thereby potentially changing the dynamics of E. coli and T4 if T4 was controlling E. coli in our environment.

In conclusion, specific bacteria that are capable of eliminating specific viruses changes our vision of food webs and represent a noteworthy avenue to explore to control harmful bacteriophages that disrupt dairy fermentation.

Author Contributions: Conceptualization, J.-J.G. and O.Z.; methodology, A.B., J.-J.G., and O.Z.; software, M.A.; validation, L.C., M.-A.P., J.-J.G., and O.Z.; formal analysis, J.-J.G. and O.Z.; investigation, A.B., J.-J.G., M.-A.P., H.N., and O.Z.; resources, A.B. and O.Z.; data curation, L.C.; writing-original draft preparation, J.-J.G. and O.Z.; writing-review and editing, all.; visualization, O.Z.; supervision, J.-J.G. and O.Z.; project administration, J.-J.G. and O.Z.; funding acquisition, O.Z. All authors have read and agreed to the published version of the manuscript.

Funding: This research received no external funding.

Institutional Review Board Statement: Not applicable. 
Informed Consent Statement: Not applicable.

Data Availability Statement: High-throughput sequencing data have been deposited on NCBI ( https: / / www.ncbi.nlm.nih.gov/bioproject) (accessed on 11 August 2021)under accession number PRJNA650397, and the genome of Aeromonas_isolate_007 is accessible with the BioSample accession number SAMN17689348.

Acknowledgments: We thank Caroline Achard for insights on bacteriophage capture and Martin Beaumont and Amira Bousleh for the qPCR of the internal standard. Electronic microscopy work benefited from the facilities and expertise of MIMA2 MET-GABI, INRA, Agroparistech, 78352 Jouyen-Josas, France. Sequencing was performed in collaboration with the GeT core facility, Toulouse, France (http:/ / get.genotoul.fr) (accessed on 11 August 2021), supported by the France Génomique National infrastructure, funded as part of "Investissement d'avenir" program managed by the Agence Nationale pour la Recherche (contract ANR-10-INBS-09). Figures were created by Biorender.

Conflicts of Interest: The authors declare no conflict of interest. The funders had no role in the design of the study; in the collection, analyses, or interpretation of data; in the writing of the manuscript, or in the decision to publish the results.

\section{Appendix A}

The analysis of the whole genome confirms that Aeromonas_Isolate_007_151020 belongs to an intermediate clade between the Aeromonas media and Aeromonas rivipollensis species.

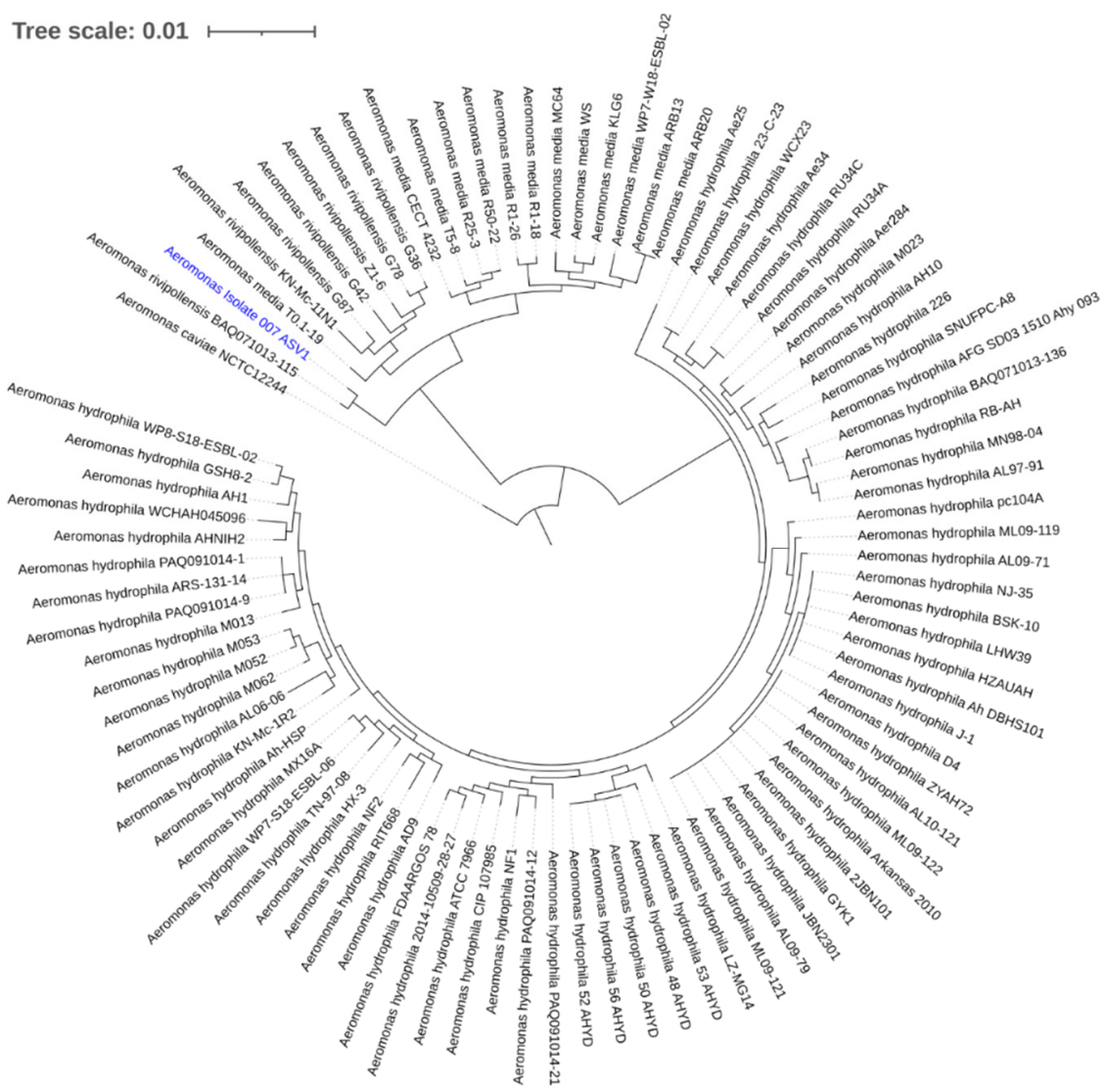

Figure A1. Phylogenetic tree of Aeromonas_Isolate_007_151020. 


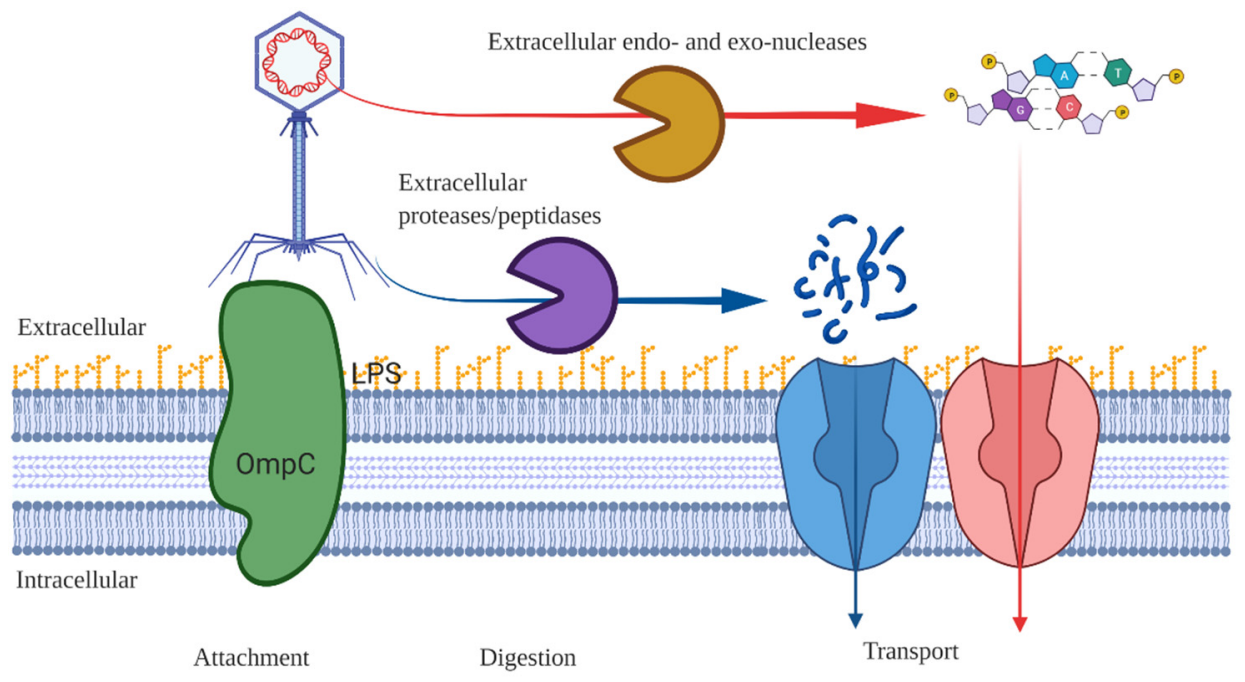

Figure A2. Schematic representation of the capture, digestion, and absorption of the T4 phages by Aeromonas sp. Since T4 phages are large particles (not to scale in the figure), we assume that Aeromonas captures the T4 phages due to its similarity with the cell wall of E. coli. Once captured, the proteins of the capsid may be digested by the extracellular proteases present in Aeromonas sp. and the DNA could be degraded as well. The products of these degradations could be ingested by Aeromonas via common transporters.

\section{Appendix B}

The functional annotation was performed with RAST8, eggNOG-mapper (v2.0.0)9 and TMHMM10 to predict the extracellular location of the proteins. The results are reported in the table below. 
Table A1. Annotation of the Aeromonas proteins putatively involved in the capture, digestion, and absorption of T4 phages, which are reported in the table below.

\begin{tabular}{|c|c|c|c|c|c|c|}
\hline Putative Function & RAST Protein Id & Contig Id & RAST_Function & TMHMM Inside & $\begin{array}{c}\text { TMHMM } \\
\text { Transmembrane }\end{array}$ & TMHMM Outside \\
\hline \multirow{3}{*}{ CAPTURE } & fig | 642.770.peg.2774 & NODE_2_length_947468_cov_91.192050 & \multirow{3}{*}{ Outer_membrane_porin_OmpC } & 1 & 1 & 1 \\
\hline & fig | 642.770.peg.1967 & NODE_1_length_1964260_cov_90.024368 & & 0 & 0 & 1 \\
\hline & fig | 642.770.peg.3181 & NODE_3_length_439005_cov_94.027299 & & 0 & 0 & 1 \\
\hline \multirow{25}{*}{$\begin{array}{l}\text { Extracellular } \\
\text { DIGESTION of } \\
\text { large proteins }\end{array}$} & fig | 642.770.peg.202 & NODE_1_length_1964260_cov_90.024368 & putative_extracellular_serine_protease & 0 & 0 & 1 \\
\hline & fig 1 642.770.peg.309 & NODE_1_length_1964260_cov_90.024368 & Uncharacterized_protease_YhbU & 0 & 0 & 1 \\
\hline & fig | 642.770.peg.653 & NODE_1_length_1964260_cov_90.024368 & Tail-specific_protease_precursor_(EC_3.4.21.102) & 0 & 0 & 1 \\
\hline & fig | 642.770.peg.664 & NODE_1_length_1964260_cov_90.024368 & Lon_protease_homolog_YcbZ & 0 & 0 & 1 \\
\hline & fig | 642.770.peg.903 & NODE_1_length_1964260_cov_90.024368 & ATP-dependent_protease_La_(EC_3.4.21.53)_Type_I & 0 & 0 & 1 \\
\hline & fig | 642.770.peg.904 & NODE_1_length_1964260_cov_90.024368 & ATP-dependent_Clp_protease_ATP-binding_subunit_ClpX & 0 & 0 & 1 \\
\hline & fig | 642.770.peg.905 & NODE_1_length_1964260_cov_90.024368 & ATP-dependent_Clp_protease_proteolytic_subunit_ClpP_(EC_3.4.21.92) & 0 & 0 & 1 \\
\hline & fig | 642.770.peg.919 & NODE_1_length_1964260_cov_90.024368 & Protease_III_precursor_(EC_3.4.24.55) & 0 & 0 & 1 \\
\hline & fig | 642.770.peg.976 & NODE_1_length_1964260_cov_90.024368 & ATP-dependent_Clp_protease_ATP-binding_subunit_ClpA & 0 & 0 & 1 \\
\hline & fig | 642.770.peg.1312 & NODE_1_length_1964260_cov_90.024368 & Protease_II_(EC_3.4.21.83) & 0 & 0 & 1 \\
\hline & fig | 642.770.peg.1793 & NODE_1_length_1964260_cov_90.024368 & Uncharacterized_protease_YegQ & 0 & 0 & 1 \\
\hline & fig | 642.770.peg.1989 & NODE_1_length_1964260_cov_90.024368 & $\begin{array}{c}\text { Vibriolysin_extracellular_zinc_protease_(EC_3.4.24.25)_@_Pseudolysin_- } \\
\text { extracellular_zinc_protease_(EC_3.4.24.26) }\end{array}$ & 0 & 0 & 1 \\
\hline & fig | 642.770.peg.3280 & NODE_3_length_439005_cov_94.027299 & Protease_II_(EC_3.4.21.83) & 0 & 0 & 1 \\
\hline & fig | 642.770.peg.3795 & NODE_5_length_206066_cov_93.597574 & ATP-dependent_hsl_protease_ATP-binding_subunit_HslU & 0 & 0 & 1 \\
\hline & fig | 642.770.peg.3796 & NODE_5_length_206066_cov_93.597574 & ATP-dependent_protease_subunit_HslV_(EC_3.4.25.2) & 0 & 0 & 1 \\
\hline & fig | 642.770.peg.12 & NODE_10_length_72653_cov_95.226534 & Oligopeptidase_A_(EC_3.4.24.70) & 0 & 0 & 1 \\
\hline & fig | 642.770.peg.67 & NODE_10_length_72653_cov_95.226534 & Xaa-Pro_dipeptidase_PepQ_(EC_3.4.13.9) & 0 & 0 & 1 \\
\hline & fig | 642.770.peg.308 & NODE_1_length_1964260_cov_90.024368 & Uncharacterized_peptidase_U32_family_member_YhbV & 0 & 0 & 1 \\
\hline & fig | 642.770.peg.319 & NODE_1_length_1964260_cov_90.024368 & Peptidase_B_(EC_3.4.11.23) & 0 & 0 & 1 \\
\hline & fig | 642.770.peg.324 & NODE_1_length_1964260_cov_90.024368 & Peptidase_B_(EC_3.4.11.23) & 0 & 0 & 1 \\
\hline & fig | 642.770.peg.496 & NODE_1_length_1964260_cov_90.024368 & Aminopeptidase_PepA-related_protein & 0 & 0 & 1 \\
\hline & fig | 642.770.peg.654 & NODE_1_length_1964260_cov_90.024368 & Membrane_alanine_aminopeptidase_N_(EC_3.4.11.2) & 0 & 0 & 1 \\
\hline & fig | 642.770.peg.1189 & NODE_1_length_1964260_cov_90.024368 & Oligoendopeptidase_F-like_protein & 0 & 0 & 1 \\
\hline & fig | 642.770.peg.1360 & NODE_1_length_1964260_cov_90.024368 & Tripeptide_aminopeptidase_(EC_3.4.11.4) & 0 & 0 & 1 \\
\hline & fig | 642.770.peg.1462 & NODE_1_length_1964260_cov_90.024368 & Probable_endopeptidase_NlpC & 0 & 0 & 1 \\
\hline
\end{tabular}


Table A1. Cont.

\begin{tabular}{|c|c|c|c|c|c|c|}
\hline Putative Function & RAST Protein Id & Contig Id & RAST_Function & TMHMM Inside & $\begin{array}{c}\text { TMHMM } \\
\text { Transmembrane }\end{array}$ & TMHMM Outside \\
\hline \multirow{14}{*}{$\begin{array}{l}\text { Extracellular } \\
\text { DIGESTION of } \\
\text { large proteins }\end{array}$} & fig | 642.770.peg.1502 & NODE_1_length_1964260_cov_90.024368 & FIG009095:_D_D-carboxypeptidase_family_protein & 0 & 0 & 1 \\
\hline & fig | 642.770.peg.1638 & NODE_1_length_1964260_cov_90.024368 & Peptidase_M23/M37_family & 0 & 0 & 1 \\
\hline & fig | 642.770.peg.1722 & NODE_1_length_1964260_cov_90.024368 & Membrane_proteins_related_to_metalloendopeptidases & 0 & 0 & 1 \\
\hline & fig | 642.770.peg.1792 & NODE_1_length_1964260_cov_90.024368 & L_D-transpeptidase_>_YbiS & 0 & 0 & 1 \\
\hline & fig | 642.770.peg.1981 & NODE_1_length_1964260_cov_90.024368 & L_D-transpeptidase_>_YbiS & 0 & 0 & 1 \\
\hline & figl 642.770.peg.2129 & NODE_2_length_947468_cov_91.192050 & Alpha-aspartyl_dipeptidase_Peptidase_E_(EC_3.4.13.21) & 0 & 0 & 1 \\
\hline & fig | 642.770.peg.2153 & NODE_2_length_947468_cov_91.192050 & Thermostable_carboxypeptidase_1_(EC_3.4.17.19) & 0 & 0 & 1 \\
\hline & fig | 642.770.peg.2266 & NODE_2_length_947468_cov_91.192050 & Methionine_aminopeptidase_(EC_3.4.11.18) & 0 & 0 & 1 \\
\hline & fig | 642.770.peg.2291 & NODE_2_length_947468_cov_91.192050 & Peptidase_M13_family & 0 & 0 & 1 \\
\hline & fig | 642.770.peg.2456 & NODE_2_length_947468_cov_91.192050 & $\begin{array}{l}\gamma \text {-glutamyltranspeptidase_(EC_2.3.2.2) } \\
\text { @_Glutathione_hydrolase_(EC_3.4.19.13) }\end{array}$ & 0 & 0 & 1 \\
\hline & fig | 642.770.peg.3506 & NODE_4_length_411610_cov_92.800192 & Xaa-Pro_aminopeptidase_(EC_3.4.11.9) & 0 & 0 & 1 \\
\hline & fig | 642.770.peg.3576 & NODE_4_length_411610_cov_92.800192 & Prolyl_endopeptidase_(EC_3.4.21.26) & 0 & 0 & 1 \\
\hline & fig | 642.770.peg.4017 & NODE_6_length_154685_cov_89.330397 & Oligoendopeptidase_F-like_protein & 0 & 0 & 1 \\
\hline & fig | 642.770.peg.4147 & NODE_7_length_126480_cov_93.962673 & Bacterial_leucyl_aminopeptidase_(EC_3.4.11.10) & 0 & 0 & 1 \\
\hline \multirow{3}{*}{ DNA DIGESTION } & fig | 642.770.peg.760 & NODE_1_length_1964260_cov_90.024368 & Extracellular_and/or_outer_membrane_deoxyribonuclease_NucH/SO1066 & 0 & 0 & 1 \\
\hline & fig | 642.770.peg.1884 & NODE_1_length_1964260_cov_90.024368 & DNA/RNA_endonuclease_G & 1 & 1 & 1 \\
\hline & fig | 642.770.peg.1925 & NODE_1_length_1964260_cov_90.024368 & Extracellular_and/or_outer_membrane_deoxyribonuclease_NucH/SO1066 & 0 & 0 & 1 \\
\hline \multirow{10}{*}{$\begin{array}{l}\text { Peptide } \\
\text { TRANSPORT into } \\
\text { the cell }\end{array}$} & fig | 642.770.peg.2135 & NODE_2_length_947468_cov_91.192050 & Succinyl-CoA_synthetase_alpha_subunit & 0 & 0 & 1 \\
\hline & fig | 642.770.peg.274 & NODE_1_length_1964260_cov_90.024368 & ABC_transporter_permease_protein_1_(cluster_5_nickel/peptides/opines) & 4 & 6 & 3 \\
\hline & fig | 642.770.peg.275 & NODE_1_length_1964260_cov_90.024368 & ABC_transporter_permease_protein_2_(cluster_5_nickel/peptides/opines) & 3 & 5 & 3 \\
\hline & fig | 642.770.peg.1213 & NODE_1_length_1964260_cov_90.024368 & Oligopeptide_ABC_transporter_permease_protein_OppC_(TC_3.A.1.5.1) & 4 & 6 & 3 \\
\hline & fig | 642.770.peg.1214 & NODE_1_length_1964260_cov_90.024368 & Oligopeptide_ABC_transporter_permease_protein_OppB_(TC_3.A.1.5.1) & 4 & 6 & 3 \\
\hline & fig | 642.770.peg.1215 & NODE_1_length_1964260_cov_90.024368 & $\begin{array}{l}\text { Oligopeptide_ABC_transporter_substrate- } \\
\text { binding_protein_OppA_(TC_3.A.1.5.1) }\end{array}$ & 1 & 1 & 1 \\
\hline & fig | 642.770.peg.1819 & NODE_1_length_1964260_cov_90.024368 & Dipeptide_ABC_transporter_permease_protein_DppC_(TC_3.A.1.5.2) & 4 & 6 & 3 \\
\hline & fig | 642.770.peg.1820 & NODE_1_length_1964260_cov_90.024368 & ABC_transporter_permease_protein_1_(cluster_5_nickel/peptides/opines) & 4 & 6 & 3 \\
\hline & fig | 642.770.peg.1913 & NODE_1_length_1964260_cov_90.024368 & ABC_transporter_permease_protein_2_(cluster_5__nickel/peptides/opines) & 4 & 6 & 3 \\
\hline & fig | 642.770.peg.1914 & NODE_1_length_1964260_cov_90.024368 & ABC_transporter_permease_protein_1_(cluster_5_nickel/peptides/opines) & 4 & 6 & 3 \\
\hline
\end{tabular}


Table A1. Cont.

\begin{tabular}{|c|c|c|c|c|c|c|}
\hline Putative Function & RAST Protein Id & Contig Id & RAST_Function & TMHMM Inside & $\begin{array}{c}\text { TMHMM } \\
\text { Transmembrane }\end{array}$ & TMHMM Outside \\
\hline \multirow{6}{*}{$\begin{array}{l}\text { DNA TRANSPORT } \\
\text { into the cell }\end{array}$} & fig | 642.770.peg.2922 & NODE_3_length_439005_cov_94.027299 & $\mathrm{Na}+$ _dependent_nucleoside_transporter_NupC & 5 & 9 & 4 \\
\hline & fig | 642.770.peg.2967 & NODE_3_length_439005_cov_94.027299 & $\mathrm{Na}+$ dependent_nucleoside_transporter_NupC & 4 & 8 & 4 \\
\hline & fig | 642.770.peg.3112 & NODE_3_length_439005_cov_94.027299 & $\mathrm{Na}+$ _dependent_nucleoside_transporter_NupC & 4 & 8 & 4 \\
\hline & fig | 642.770.peg.4145 & NODE_7_length_126480_cov_93.962673 & Predicted_nucleoside_ABC_transporter_permease_1_component & 6 & 10 & 5 \\
\hline & fig | 642.770.peg.4146 & NODE_7_length_126480_cov_93.962673 & Predicted_nucleoside_ABC_transporter_permease_2_component & 4 & 7 & 4 \\
\hline & fig | 642.770.peg.177 & NODE_13_length_22868_cov_91.969299 & DNA_uptake_protein & 0 & 0 & 1 \\
\hline
\end{tabular}




\section{Appendix C}

Appendix $C$ describes the purity of the initial solution of $T 4$ phages.

T4-phage particles labeled with ${ }^{13} \mathrm{C}$ were produced on Escherichia coli B cells (DSM 613) grown in $\mathrm{M} 9$ minimal medium with ${ }^{13} \mathrm{C}$-glucose as the sole carbon source. The $\mathrm{M} 9$ medium was prepared using M9, Minimal Salts, $5 \times$ (Sigma-Aldrich) by adding $\mathrm{MgSO}_{4}$ (Sigma-Aldrich) and $\mathrm{CaCl}_{2}$ (Sigma-Aldrich) at final concentrations of $1 \mathrm{mM}$ and D-Glucose at a final concentration of $10 \mathrm{~g} / \mathrm{L}$. Moreover, additional salts were added to favor phage adsorption (solution of $\mathrm{CaCl}_{2} 0.5 \mathrm{M}$ and $\mathrm{MgCl}_{2} 1 \mathrm{M}$, diluted 1000 times in the culture medium). More precisely, starting from an E. coli stock of cells frozen in LB and glycerol, two successive overnight pre-cultures were grown in LB medium (LB broth, Fisher, Camas, WA, USA). Subsequently, $5 \times 20 \mathrm{~mL}$ of M9 minimal medium containing D-Glucose- ${ }^{13} \mathrm{C} 6$ as the sole carbon source $(10 \mathrm{~g} / \mathrm{L})$ were each inoculated with $20 \mu \mathrm{L}$ of the second E. coli preculture; approximately 1500 T4-phage particles (DSM 4505, in PFU) were added. Finally, $20 \mu \mathrm{L}$ of a solution containing $0.5 \mathrm{M} \mathrm{CaCl}_{2}$ and $1 \mathrm{M} \mathrm{MgCl}_{2}$ were also added in each case to favor phage adsorption.

After $30 \mathrm{~h}$ of incubation at $37{ }^{\circ} \mathrm{C}$ under $50 \mathrm{rpm}$ agitation to allow the phages to replicate, the T4 phage particles were collected: the cultures were centrifuged for $15 \mathrm{~min}$ at $5000 \times g$ at $10^{\circ} \mathrm{C}$ to eliminate the large cellular debris. The supernatants were collected and filtered through $0.22 \mu \mathrm{m}$ pore-sized PES filters (Milipore, Burlington, MA, USA) to eliminate fine cellular debris. They were subsequently incubated overnight in $8 \% w / v$ PEG 6000 and $0.5 \mathrm{M} \mathrm{NaCl}$ solution at $4{ }^{\circ} \mathrm{C}$ to aggregate the viral particles with minimal losses. The phage aggregates were collected by centrifugation at $20,000 \times g$ for $30 \mathrm{~min}$ at $4{ }^{\circ} \mathrm{C}$. The pellets were resuspended in SM buffer $\left(100 \mathrm{mM} \mathrm{NaCl}, 8 \mathrm{mM} \mathrm{MgSO}_{4}, 50 \mathrm{mM}\right.$ Tris $\mathrm{pH}$ 7.5), and were centrifuged once more at $20,000 \times g$ for $4 \mathrm{~h}$ at $4{ }^{\circ} \mathrm{C}$. The viral particles were finally suspended in $1.4 \mathrm{~mL}$ of SM buffer and were stored at $4{ }^{\circ} \mathrm{C}$ before use.

To obtain the unlabeled T4 phage particles, the same procedure was used, except unlabeled glucose was employed in the M9 minimal medium.

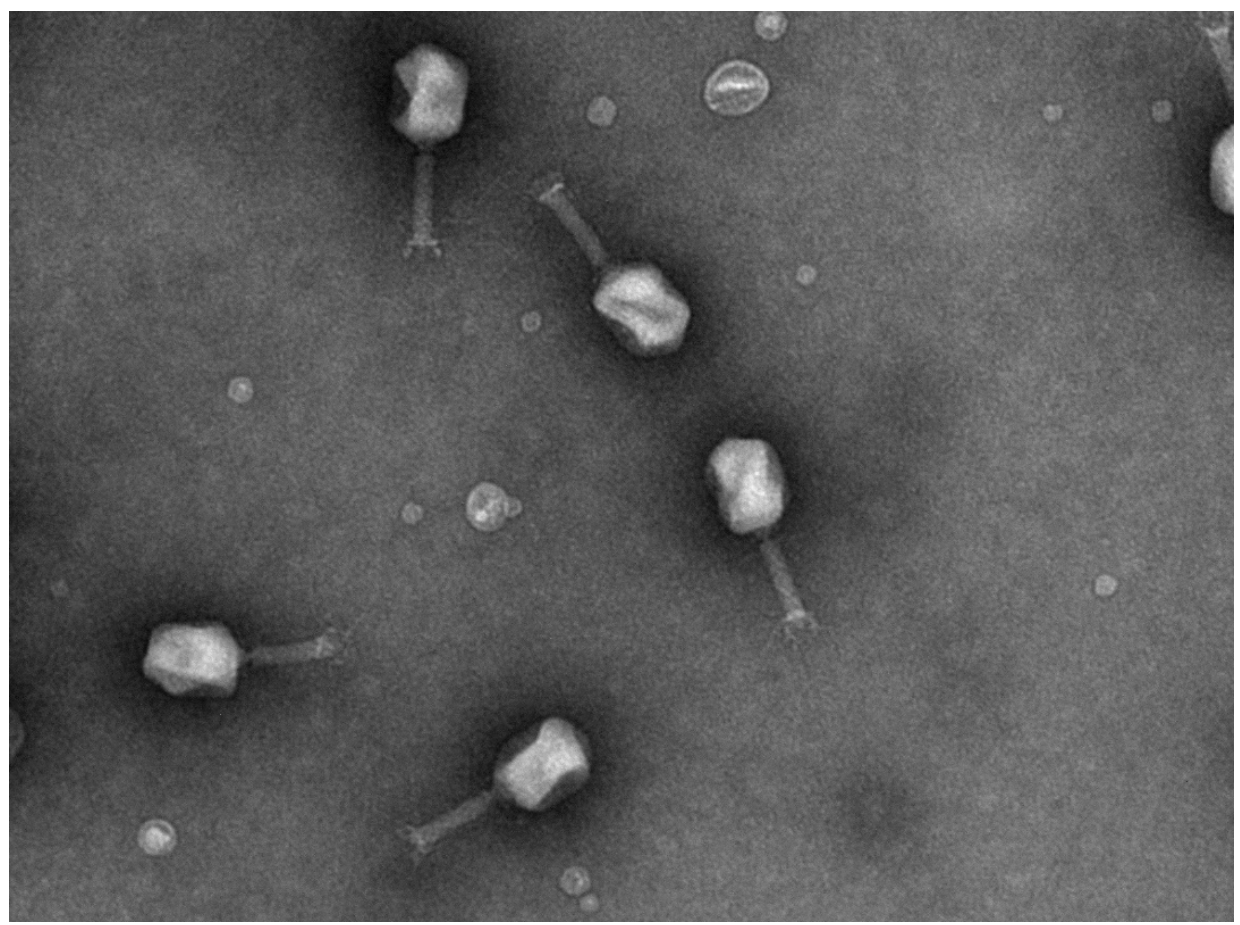

Figure A3. Cont. 


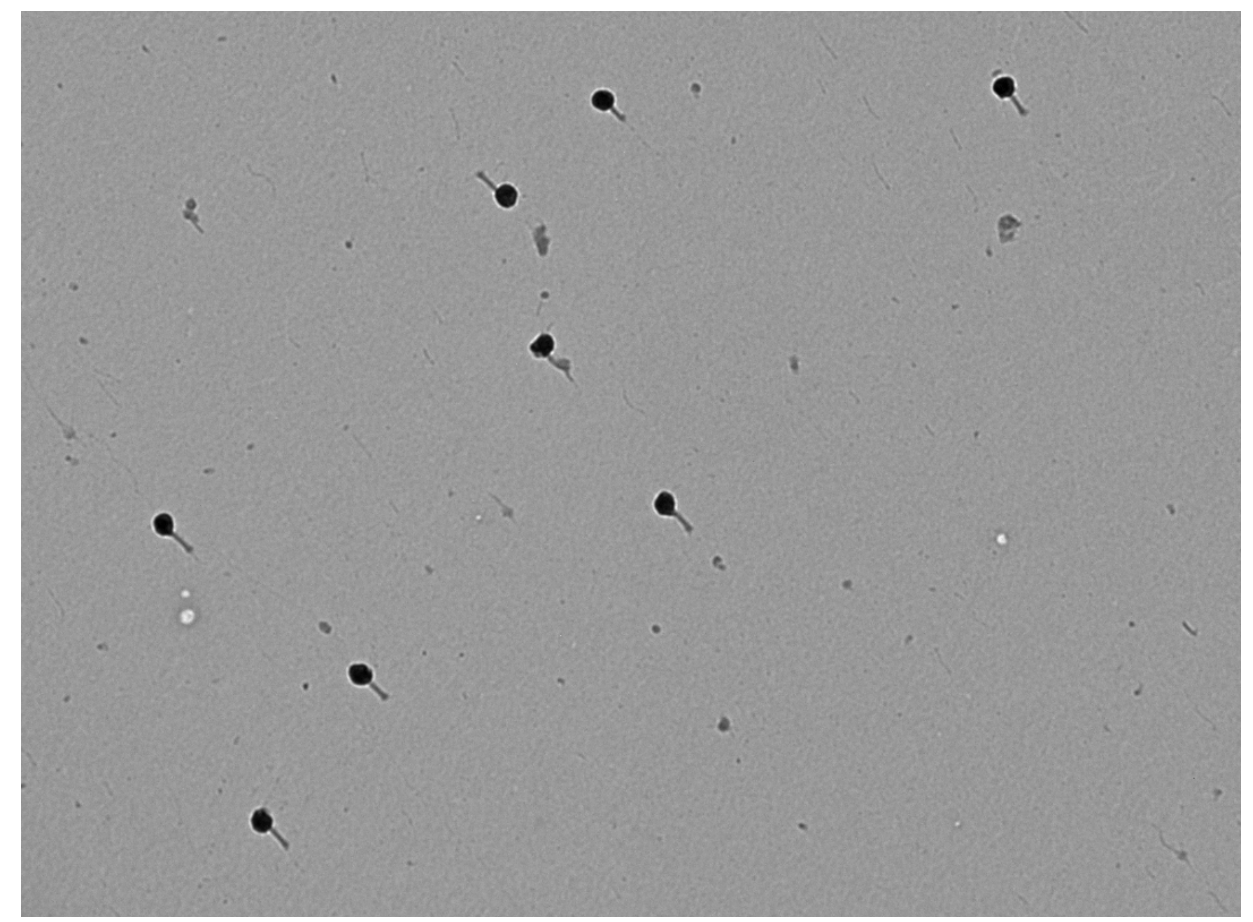

Figure A3. Purity of the bacteriophage preparation. We checked the purity of the bacteriophage preparation by means of electronic microscopy. Materials were directly adsorbed onto a carbon film membrane on a 300-mesh copper grid, stained with $1 \%$ uranyl acetate, dissolved in distilled water, and dried at room temperature. Grids were examined with a Hitachi HT7700 electron microscope operated at $80 \mathrm{kV}$ (Elexience-France), and the images were acquired with a charge-coupled device camera (AMT).

\section{References}

1. Bar-On, Y.M.; Phillips, R.; Milo, R. The biomass distribution on Earth. Proc. Natl. Acad. Sci. USA 2018, 115, 6506-6511. [CrossRef]

2. Comeau, A.M.; Krisch, H.M. The capsid of the T4 phage superfamily: The evolution, diversity, and structure of some of the most prevalent proteins in the biosphere. Mol. Biol. Evol. 2008, 25, 1321-1332. [CrossRef]

3. Jover, L.F.; Effler, T.C.; Buchan, A.; Wilhelm, S.W.; Weitz, J.S. The elemental composition of virus particles: Implications for marine biogeochemical cycles. Nat. Rev. Microbiol. 2014, 12, 519-528. [CrossRef] [PubMed]

4. Mondal, T.; Rouch, D.A.; Thurbon, N.; Smith, S.R.; Deighton, M.A. Factors affecting decay of Salmonella Birkenhead and coliphage MS2 during mesophilic anaerobic digestion and air drying of sewage sludge. J. Water Health 2015, 13, 459-472. [CrossRef] [PubMed]

5. Nasser, A.M.; Glozman, R.; Nitzan, Y. Contribution of microbial activity to virus reduction in saturated soil. Water Res. 2002, 36, 2589-2595. [CrossRef]

6. Gonzalez, J.M.; Suttle, C.A. Grazing by Marine Nanoflagellates on Viruses and Virus-Sized Particles-Ingestion and Digestion. Mar. Ecol. Prog. Ser. 1993, 94, 1-10. [CrossRef]

7. Brown, J.M.; Labonté, J.M.; Brown, J.; Record, N.R.; Poulton, N.J.; Sieracki, M.E.; Logares, R.; Stepanauskas, R. Single Cell Genomics Reveals Viruses Consumed by Marine Protists. Front. Microbiol. 2020, 11, 524828. [CrossRef]

8. Zemb, O.; Achard, C.S.; Hamelin, J.; De Almeida, M.-L.; Gabinaud, B.; Cauquil, L.; Verschuren, L.M.G.; Godon, J.-J. Absolute quantitation of microbes using 16S rRNA gene metabarcoding: A rapid normalization of relative abundances by quantitative PCR targeting a 16S rRNA gene spike-in standard. Microbiologyopen 2020, 9, e977. [CrossRef] [PubMed]

9. Magoc, T.; Salzberg, S.L. FLASH: Fast length adjustment of short reads to improve genome assemblies. Bioinformatics 2011, 27, 2957-2963. [CrossRef]

10. Callahan, B.J.; McMurdie, P.J.; Rosen, M.J.; Han, A.W.; Johnson, A.J.; Holmes, S.P. DADA2: High-resolution sample inference from Illumina amplicon data. Nat. Methods 2016, 13, 581-583. [CrossRef]

11. Quast, C.; Pruesse, E.; Yilmaz, P.; Gerken, J.; Schweer, T.; Yarza, P.; Peplies, J.; Glockner, F.O. The SILVA ribosomal RNA gene database project: Improved data processing and web-based tools. Nucleic Acids Res. 2013, 41, D590-D596. [CrossRef]

12. Větrovský, T.; Baldrian, P. The Variability of the $16 \mathrm{~S}$ rRNA Gene in Bacterial Genomes and Its Consequences for Bacterial Community Analyses. PLoS ONE 2013, 8, e57923. [CrossRef] [PubMed]

13. Trousselier, M.; Bouvy, M.; Courties, C.; Dupuy, C. Variation of carbon content among bacterial species under starvation condition. Aquat. Microb. Ecol. 1997, 13, 113-119. [CrossRef] 
14. Buckley, D.H.; Huangyutitham, V.; Hsu, S.F.; Nelson, T.A. Stable isotope probing with $15 \mathrm{~N}$ achieved by disentangling the effects of genome $\mathrm{G}+\mathrm{C}$ content and isotope enrichment on DNA density. Appl. Environ. Microbiol. 2007, 73, 3189-3195. [CrossRef] [PubMed]

15. Janda, J.M.; Abbott, S.L. The genus Aeromonas: Taxonomy, pathogenicity, and infection. Clin. Microbiol. Rev. 2010, 23, 35-73. [CrossRef] [PubMed]

16. Ye, L.; Zhang, T.; Wang, T.; Fang, Z. Microbial structures, functions, and metabolic pathways in wastewater treatment bioreactors revealed using high-throughput sequencing. Environ. Sci. Technol. 2012, 46, 13244-13252. [CrossRef] [PubMed]

17. Noonan, B.; Trust, T.J. The synthesis, secretion and role in virulence of the paracrystalline surface protein layers of Aeromonas salmonicida and A. hydrophila. FEMS Microbiol. Lett. 1997, 154, 1-7. [CrossRef] [PubMed]

18. Sleytr, U.B.; Schuster, B.; Egelseer, E.-M.; Pum, D. S-layers: Principles and applications. FEMS Microbiol. Rev. 2014, 38, 823-864. [CrossRef]

19. Islam, M.Z.; Fokine, A.; Mahalingam, M.; Zhang, Z.; Garcia-Doval, C.; van Raaij, M.J.; Rossmann, M.G.; Rao, V.B. Molecular anatomy of the receptor binding module of a bacteriophage long tail fiber. PLoS Pathog. 2019, 15, e1008193. [CrossRef]

20. Janda, J.M. Biochemical and exoenzymatic properties of Aeromonas species. Diagn. Microbiol. Infect. Dis. 1985, 3, $223-232$. [CrossRef]

21. Seshadri, R.; Joseph, S.W.; Chopra, A.K.; Sha, J.; Shaw, J.; Graf, J.; Haft, D.; Wu, M.; Ren, Q.; Rosovitz, M.J.; et al. Genome Sequence of Aeromonas hydrophila ATCC 7966 ${ }^{\mathrm{T}}$ : Jack of All Trades. J. Bacteriol. 2006, 188, 8272-8282. [CrossRef] [PubMed] 